\title{
Is the bioavailability index applicable for trace elements in different types of soil?
}

\author{
Shuzhen Zhang and Xiao-quan Shan* \\ Research Center for Eco-Environmental Sciences, Chinese Academy of Sciences, PO Box 2871, Beijing \\ 100085, China
}

*To whom all correspondence should be addressed: E-mail: xiaoquan@mail.rcees.ac.cn

\begin{abstract}
The bioavailability index $(\mathrm{BI})$ is defined as the proportion of reduction in a plant's accumulation of an element, caused by the removal of the extractable fraction of the element of interest from the soil. The BI and corresponding experimental methods were quantitatively applied to evaluate the bioavailability of trace elements in five Chinese soils. The soil was first extracted with various reagents (DTPA, $\mathrm{HCl}$ and $\mathrm{NH}_{2} \mathrm{OH}$. $\mathrm{HCl}$ ) separately, to remove the extractable elements. The soil, after extraction, was washed with deionised water to eliminate the extractant used in the fractionation analysis. Then the $\mathrm{pH}$ of the soil was re-adjusted with $\mathrm{CaO}$. The soil was then fertilised and incubated in a greenhouse for four weeks. Tests showed that after incubation the $\mathrm{pH}$, cation exchange capacity (CEC) and organic matter (OM) of the treated soil were close to their original values. Wheat (Triticum aestivum L.) was planted in both the untreated and treated soil for eight weeks. After harvest the plant concentrations of the elements $\mathrm{Cr}, \mathrm{Mn}, \mathrm{Co}, \mathrm{Ni}, \mathrm{Zn}, \mathrm{Cu}, \mathrm{Cd}$, and $\mathrm{Pb}$ were analysed by inductively coupled plasma mass spectrometry (ICPMS). Trace element accumulation by plants grown in the treated soil was reduced significantly compared with that of plants grown in the untreated soil. The results showed that BI values were in the order $\mathrm{BI}(\mathrm{DTPA})>\mathrm{BI}(\mathrm{HCl})>\mathrm{BI}\left(\mathrm{NH}_{2} \mathrm{OH} . \mathrm{HCl}\right)$. This indicated that the DTPA-extractable fraction represented a highly available fraction of the total content. Variations of $\mathrm{Bl}$ among different trace elements show that $\mathrm{Cr}$, Mn, $\mathrm{Zn}$ and $\mathrm{Co}$ have a higher $\mathrm{BI}$, in general for the elements tested, whereas, $\mathrm{Cu}, \mathrm{Cd}$ and $\mathrm{Pb}$ have lower values. There are also slight differences in the $\mathrm{BI}$ among soils. However, no significant relationship could be found between the $\mathrm{BI}$ and the soil characteristics.
\end{abstract}

Keywords: bioavailability index, speciation, soil, trace element.

\section{INTRODUCTION}

In recent years, many studies have been conducted to identify and evaluate the bioavailability of trace elements in soils, in order to assess the potential contamination of the food chain induced by soils (Maiz et al., 1997; Quevauviller et al., 1996; Kennedy et al., 1997). In practice, most of the approaches estimate the amount of metal extracted from soils by various procedures, and correlate it with the metal content of plants. The correlation coefficients are normally used as the criterion of bioavailability. If plant accumulation of an element is significantly correlated with an extractable fraction, the fraction of the element is considered to be a good measure of plant bioavailability.
The extraction method and correlation analysis have some associated drawbacks, although they can still yield some useful information. Bioavailability depends on many factors such as soil properties and plant species. Unpredictable variations may greatly lower the degree of correlation and, in some cases, even cause a negative correlation of values between the extractable content of elements in soils, and the total content of the element in plants (Davies, 1992; Singh and Narwal, 1984; Alegria et al., 1991). Alegira et al. (1991) found the highest correlation values between the total soil content and the uptake of $\mathrm{Ni}$ and $\mathrm{Cd}$ by vegetable species, whereas, the correlation between the extractable content of soils and the total content of $\mathrm{Cd}$ in leaves or stems was found to be negative. In other 
research conducted by Singh and Narwal (1984) on Co, most of the extractants tested had a negative correlation with uptake by rape. For $\mathrm{Ni}$, extraction by $\mathrm{NH}_{4} \mathrm{OAc}$ (pH7.0) yielded negative correlation coefficients with $\mathrm{Ni}$ concentration in plant. It is difficult to interpret the negative correlation coefficients from the point of bioavailability. We cannot simply conclude that the extractants used are not adequate indicators of plant availability. On the other hand, the use of a fractionation method only provides empirical data, which are often not applicable to practical situations and natural field conditions, or only applicable to a narrow range of soil types. A final difficulty is related to the inherent nature of the statistical analysis itself, which necessitates a large number of soils, and it is better to use a wide range of metal concentrations to perform a reliable correlation analysis. Therefore, there is a need to develop a method, which could simply and reliably estimate plant availability as well as predict the uptake of trace metals by plants. Thus it would also evaluate the potential risk of these elements in contaminated environments.

Chen et al. (1996) presented a bioavailability index and the corresponding experimental method for the quantitative evaluation of plant availability of trace elements in soils. Since extractable trace elements generally represent the readily available fraction of the elements in soils, soils were first treated with an extractant, followed by $\mathrm{pH}$ adjustment and fertilisation. Crops were planted in both the treated and untreated soils. The BI was calculated as the following

$$
\mathrm{BI}=\frac{\Delta C_{\mathrm{P}} / C_{\mathrm{P}}^{0}}{C_{\mathrm{e}} / C_{\mathrm{t}}}
$$

Where $\Delta C_{\mathrm{p}}$ is the difference of the element content between the plants grown in the untreated and treated soils, $C_{P}^{0}$ is the element content in the plant grown in the untreated soil, $C_{\mathrm{e}}$ and $C_{\mathrm{t}}$ are the extractable content of the element and total concentration of the element in the soil, respectively. Therefore, the BI describes the proportion of the reduction of trace element uptake by plants which is attributable to the removal of the extractable fraction of the elements from soils. If removing a relatively small fraction of the total element content from the soil caused a significant reduction in the plant's accumulation of the element, a high BI value would be obtained. Consequently it could be concluded that this fraction was of high bioavailability.

The BI is a simple and a quantitative measurement for the bioavailability of different extractable fractions. However, in the previous study (Chen et al., 1996) only two calcareous soils were tested. As we know, the physical and chemical characteristics of soils may influence the bioavailability of trace metals in the soils. Therefore, further work with different soils is necessary. The aim of the present study is to investigate the application of BI to soils with different physico-chemical characteristics.

\section{MATERIALS AND METHODS}

\section{Soils}

Soil samples $(0-20 \mathrm{~cm})$ were collected from five different rural regions, stretching from northern to southern China. The soils, all of which were cultivated, varied widely in physico-chemical properties. The soil samples were air dried and ground to pass through a 2-mm sieve, homogenized and stored until analysis. Soil $\mathrm{pH}$ was measured in a 1:1 soil/water mixture. The organic matter was determined by the Walkley-Black method (Nelson and Sommers, 1982). The cation exchange capacity (CEC) was determined by the method described by Rhoades (1982). Total contents of trace elements were determined after samples were digested with $\mathrm{HNO}_{3} / \mathrm{HClO}_{4} / \mathrm{HF}$ under high pressure (Zhang and Shan, 1997). The results are listed in Table 1.

Chen et al. (1996) described the soil treatment's experimental design. Briefly, soils were first extracted using selected extractants. The extraction procedures are given in Table 2. After extraction, the soils were washed with distilled-deionised water several times to eliminate the extractant. Then the soil $\mathrm{pH}$ was adjusted by adding a certain amount of $\mathrm{CaO}$ in order to restore the soil $\mathrm{pH}$ to its approximately original level. Triplicate samples were prepared at the same time.

For the pot experiments, $1 \mathrm{~kg}$ of both treated and untreated soils were placed in plastic pots. The pots received a supplemental fertilizer with the mixture solution of ammonium nitrate and potassium orthophosphate, supplying $10,10,13 \mathrm{mg} /$ pot of elemental $\mathrm{N}, \mathrm{P}$ and $\mathrm{K}$, respectively. The soils were incubated in a greenhouse to keep a certain moisture content for 4 weeks prior to planting.

After soil incubation, winter wheat (Triticum aestivum L. ) was sown at a rate of 20 seeds per pot, and subsequently thinned to 10 plants per pot after germination. Water losses were accounted for by daily additions of deionized water to maintain a consistent moisture content. The plants, both tops and roots, were harvested 8 weeks after germination. The samples were washed thoroughly with deionized water, placed in paper bags, and dried to a constant weight at $60^{\circ} \mathrm{C}$ for $24 \mathrm{~h}$. The dried tissues were finely ground for the analysis.

\section{Instrumental analysis}

The metal concentrations in soils and plants were determined by inductively coupled plasma mass spectrometry (ICP-MS) after digestion with $\mathrm{HNO}_{3} / \mathrm{HClO}_{4} / \mathrm{HF}$ (Zhang and Shan, 1997). The extractant was analyzed 
Table 1 Selected chemical and physical properties of soils used in the pot experiments

\begin{tabular}{|c|c|c|c|c|c|}
\hline \multirow[t]{2}{*}{ Property } & \multicolumn{5}{|c|}{ Soil } \\
\hline & Soil 1 & Soil 2 & Soil 3 & Soil 4 & Soil 5 \\
\hline Location & Guiyong & Jinhua & Yunnan & Heilongjiang & Beijing \\
\hline Order & Entisol & Ultisol & Alfisol & Mollisol & Mollisol \\
\hline Texture & Silty-clay, mixed & Fine-silty, mixed & Fine-silty, mixed & Sandy-silty, mixed & Sandy-silty, mixed \\
\hline $\mathrm{pH}$ & 7.52 & 6.19 & 7.10 & 6.28 & 7.50 \\
\hline $\mathrm{CEC}\left(\mathrm{me} 100 \mathrm{~g}^{-1}\right)$ & 2.13 & 25.8 & 12.22 & 28.48 & 6.47 \\
\hline $\mathrm{OM}\left(\% \mathrm{WW}^{-1}\right)$ & 5.07 & 2.06 & 4.34 & 5.19 & 1.77 \\
\hline \multicolumn{6}{|l|}{ Total $\left(\mathrm{mg} \mathrm{kg}^{-1}\right)$} \\
\hline $\mathrm{Cr}$ & 168.3 & 84.6 & 220.7 & 102.2 & 63.4 \\
\hline $\mathrm{Mn}$ & 2870.9 & 1167.0 & 2851.7 & 1901.4 & 966.8 \\
\hline $\mathrm{Co}$ & 33.1 & 18.5 & 29.4 & 16.4 & 10.2 \\
\hline $\mathrm{Ni}$ & 49.5 & 22.2 & 63.9 & 33.4 & 18.1 \\
\hline $\mathrm{Zn}$ & 184.1 & 140.9 & 418.6 & 96.9 & 80.6 \\
\hline $\mathrm{Cu}$ & 51.5 & 22.1 & 261.9 & 26.2 & 20.2 \\
\hline $\mathrm{Cd}$ & 0.76 & 0.14 & 0.31 & 0.61 & 0.33 \\
\hline $\mathrm{Pb}$ & 25.3 & 25.6 & 81.4 & 25.2 & 23.6 \\
\hline
\end{tabular}

Table 2 Extractant and procedure used for bioavailibility index

\begin{tabular}{llll}
\hline Extractant & Composition & Soil/extractant ratio(w/v) & Shaking time \\
\hline DTPA & $0.005 \mathrm{MDTPA}+0.01 \mathrm{MCaCl}_{2}+0.1 \mathrm{M} \mathrm{TEA}($ triethanolamine) $\mathrm{pH} 7.3$ & $1 / 10$ & $2 \mathrm{~h}$ \\
$1 \mathrm{MHCl}$ & $1.0 \mathrm{M} \mathrm{HCl}$ & $1 / 10$ & $2 \mathrm{~h}$ \\
$\mathrm{NH}_{2} \mathrm{OH} \cdot \mathrm{HCl}$ & $0.05 \mathrm{M} \mathrm{NH} \mathrm{H}_{2} \mathrm{OH} \cdot \mathrm{HCl}+1 \mathrm{M} \mathrm{HCl}$ & $1 / 10$ & $2 \mathrm{~h}$ \\
\hline
\end{tabular}

after 5 dilutions. The ICP-MS was optimised with a solution of ${ }^{115} \mathrm{In}$ at $10 \mathrm{ng} \mathrm{mL}^{-1}$ in $2 \% \mathrm{HNO}_{3}$, which was also used as an internal standard to compensate for matrix suppression and signal drifts during analysis. The accuracy of the elemental analysis was checked by the determination of REEs in the certified reference materials (GSS-1, GSS-8 of soils and GBW 07605 of tea from the National Research Center for Certified Reference Materials, Beijing, China) with seven replicate samples. The results are summarised in Table 3. Good agreement was achieved between the data obtained by the present method and the certified values for both soil and tea leaves.

\section{RESULTS AND DISCUSSION}

\section{Effects of soil preparation upon soil properties}

Previous investigations have indicated that bioaccumulation of trace elements is to some extent dominated by the soil properties (Soon and Bates, 1982; Sauerbeck and Hein, 1991; Davies, 1992; MaNeal et al.; 1985). If the soil properties have changed during the treatment procedures, the reductions of the trace elements in the plants would not only be controlled by the removal of trace elements, but also influenced by the changes in soil properties.

We investigated whether the $\mathrm{pH}$ of the treated soil can be adjusted to its original condition without affecting soil properties. The $\mathrm{pH}, \mathrm{CEC}$ and $\mathrm{OM}$ of one soil sample were tested after the soil treatment. As shown in Table 4 there was no significant difference between the treated and untreated soils. Furthermore, care was taken to determine whether the soil treatment proce-

Table 3 Determination of trace elements in the certified reference materials by ICP-MS

\begin{tabular}{|c|c|c|c|c|c|c|}
\hline \multirow[t]{2}{*}{ Element } & \multicolumn{2}{|c|}{$\begin{array}{l}\text { GSS soil } \\
\left(\mu g^{-1}\right)\end{array}$} & \multicolumn{2}{|c|}{$\begin{array}{l}\text { GBSS soil } \\
\left(\mu \mathrm{g} \mathrm{g}^{-1}\right)\end{array}$} & \multicolumn{2}{|c|}{$\begin{array}{l}\text { GBW7605 tea leaves } \\
\left(\mu g^{-1}\right)\end{array}$} \\
\hline & This method* & Certified & This method* & Certified & This method* & Certified \\
\hline $\mathrm{Cr}$ & $58.5 \pm 3.1$ & $62 \pm 6$ & $70.4 \pm 1.2$ & $68 \pm 8$ & $1.5 \pm 0.2$ & 2 \\
\hline $\mathrm{Mn}$ & $1801.7 \pm 3.9$ & $1760 \pm 98$ & $667.9 \pm 4.1$ & $650 \pm 35$ & $0.28 \pm 0.03$ & $0.217 \pm 0.011$ \\
\hline $\mathrm{Co}$ & $15.0 \pm 0.8$ & $14.2 \pm 1.5$ & $11.4 \pm 0.5$ & $12.7 \pm 1.7$ & $0.21 \pm 0.02$ & 0.18 \\
\hline $\mathrm{Ni}$ & $18.9 \pm 1.0$ & $20.4 \pm 2.7$ & $30.8 \pm 1.1$ & $31.5 \pm 2.7$ & $5.8 \pm 0.4$ & $5.09 \pm 0.76$ \\
\hline $\mathrm{Zn}$ & $669 \pm 4.1$ & $680 \pm 39$ & $71.4 \pm 1.6$ & $68 \pm 6$ & $24.0 \pm 1.8$ & $22.6 \pm 1.5$ \\
\hline $\mathrm{Cu}$ & $22.3 \pm 0.8$ & $21 \pm 2$ & $25.6 \pm 2.0$ & $24.3 \pm 1.8$ & $10.01 \pm 0.2$ & $8.96 \pm 0.59$ \\
\hline $\mathrm{Cd}$ & $4.6 \pm 0.2$ & $4.3 \pm 0.6$ & $0.14 \pm 0.02$ & $0.13 \pm 0.05$ & $0.03 \pm 0.001$ & $0.023 \pm 0.004$ \\
\hline $\mathrm{Pb}$ & $92.3 \pm 1.9$ & $98 \pm 8$ & $23.1 \pm 1.2$ & $21 \pm 3$ & $0.98 \pm 0.01$ & $1.00 \pm 0.05^{*}$ \\
\hline
\end{tabular}

Mean and standard deviation from 5 determinations. 
Table 4 Selected properties of soil 5 before and after extraction treatment

\begin{tabular}{lllll}
\hline \hline & \multirow{2}{*}{ untreated } & \multicolumn{3}{c}{ treated } \\
\cline { 3 - 5 } & & DTPA & $\mathrm{HCl}$ & $\mathrm{NH}_{2} \mathrm{OH} . \mathrm{HCl}$ \\
\hline $\mathrm{pH}$ & 7.50 & 6.96 & 7.23 & 7.28 \\
$\mathrm{CEC} \mathrm{me} 100^{-1}$ & 6.47 & 5.85 & 6.63 & 6.50 \\
OM\% W W-1 & 1.38 & 1.62 & 2.00 & 1.47 \\
\hline
\end{tabular}

dures caused differences in plant growth. The experimental results indicated no significant differences between the yields of treated and untreated soils.

\section{Comparison of BI among different extractants}

Three different types of extractants, ammonium ethylenediaminetetra-acetate, hydrochloric acid and Hydroxylammonium chloride were selected for soil extraction because they represent different kinds of chemical attack in addition to being commonly used to investigate the bioavailability of elements to plants (Maiz et al., 1997; Quevauviller et al., 1996; Linday and Norvell, 1978; Das et al., 1995).

The BI values of the extractable trace elements with different extractants are listed in Tables 5(a) to 5(e) for different soils. For all the soils, the BI values were in the order of BI (DTPA $>\mathrm{BI}(\mathrm{HCl})>\mathrm{BI}\left(\mathrm{NH}_{2} \mathrm{OH} \cdot \mathrm{HCl}\right)$. This suggested that DTPA-extractable trace elements represent a highly available fraction of the total content. When this highly available fraction of the elements was removed by DTPA extraction, the element accumulation by plants was significantly affected. This result corresponded to that of previous studies on DTPA as an extractant for assessing bioavailability of micronutrient cations in soils. Randall et al. (1976) concluded that DTPA could be used successfully to determine the available Mn in low organic matter soil. Bingham et al. (1975) showed a highly significant correlation between DTPA-extractable Cd and that taken up by corn. Singh and Narwal (1984) found numerically superior correlation coefficients between $\mathrm{Cd}, \mathrm{Pb}$ and $\mathrm{Zn}$ extracted by DTPA and the total uptake of these metals by rape

Table 5 (a). BI of the extractable trace elements with different extractants for soil $1 *$

\begin{tabular}{|c|c|c|c|c|c|c|c|c|c|c|c|c|c|c|c|}
\hline \multicolumn{6}{|c|}{ Element BI of DTPA-extractable fraction } & \multicolumn{5}{|c|}{$\mathrm{BI}$ of $\mathrm{HCl}$-extractable fraction } & \multicolumn{5}{|c|}{$\mathrm{BI}$ of $\mathrm{NH}_{2} \mathrm{OH} . \mathrm{HCl}$ extractable fraction } \\
\hline & $\begin{array}{l}C_{\mathrm{E}} \\
(\%)\end{array}$ & $\begin{array}{l}\Delta C_{\mathrm{P}} \\
(\%)\end{array}$ & $\mathrm{BI}_{\mathrm{P}}$ & $\begin{array}{l}\Delta C_{\mathrm{R}} \\
(\%)\end{array}$ & $\mathrm{BI}_{\mathrm{R}}$ & $\begin{array}{l}C_{\mathrm{E}} \\
(\%)\end{array}$ & $\begin{array}{l}\Delta C_{\mathrm{P}} \\
(\%)\end{array}$ & $\mathrm{BI}_{\mathrm{P}}$ & $\begin{array}{l}\Delta C_{\mathrm{R}} \\
(\%)\end{array}$ & $\mathrm{BI}_{\mathrm{R}}$ & $\begin{array}{l}C_{\mathrm{E}} \\
(\%)\end{array}$ & $\begin{array}{l}\Delta C_{\mathrm{P}} \\
(\%)\end{array}$ & $\mathrm{BI}_{\mathrm{P}}$ & $\begin{array}{l}\Delta C_{\mathrm{R}} \\
(\%)\end{array}$ & $\mathrm{BI}_{\mathrm{R}}$ \\
\hline $\mathrm{Cr}$ & 0.80 & 25.1 & 31.4 & 21.9 & 27.4 & 3.2 & 25.6 & 8.0 & 32.0 & 10.0 & 7.2 & 26.8 & 3.7 & 49.6 & 6.9 \\
\hline $\mathrm{Mn}$ & 1.0 & 34.4 & 34.4 & 31.6 & 31.6 & 14.6 & 69.2 & 4.7 & 46.7 & 3.2 & 28.4 & 41.7 & 1.6 & 56.8 & 2.0 \\
\hline Co & 3.1 & 29.3 & 9.5 & 26.4 & 8.5 & 7.7 & 49.6 & 6.4 & 47.0 & 6.1 & 38.8 & 67.4 & 1.7 & 69.9 & 1.8 \\
\hline $\mathrm{Ni}$ & 2.6 & 30.0 & 11.5 & 35.9 & 13.8 & 10.7 & 21.4 & 2.0 & 16.1 & 1.5 & 15.6 & 24.8 & 1.6 & 29.6 & 1.9 \\
\hline $\mathrm{Zn}$ & 2.7 & 35.9 & 13.3 & 45.0 & 16.7 & 5.6 & 32.2 & 5.7 & 16.2 & 2.9 & 23.5 & 53.9 & 2.3 & 65.8 & 2.8 \\
\hline $\mathrm{Cu}$ & 10.8 & 18.3 & 1.7 & 27.0 & 2.5 & 21.9 & 24.5 & 1.1 & 35.1 & 1.6 & 28.2 & 26.0 & 0.92 & 32.6 & 1.2 \\
\hline $\mathrm{Cd}$ & 9.7 & 28.1 & 2.9 & 40.7 & 4.2 & 29.9 & 29.2 & 1.0 & 50.5 & 1.5 & 33.3 & 40.7 & 1.2 & 41.7 & 1.2 \\
\hline $\mathrm{Pb}$ & 7.5 & 33.1 & 4.4 & 33.0 & 4.4 & 44.3 & 39.9 & 0.9 & 31.0 & 0.7 & 30.9 & 24.7 & 0.8 & 60.7 & 2.0 \\
\hline
\end{tabular}

*The extractable trace elements $\left(C_{\mathrm{E}}\right)$ are expressed in percentage of the total content of the elements in the untreated soil and plan accumulation reduction of the elements in plant $\left(\Delta C_{\mathrm{P}}\right)$ and in $\operatorname{root}\left(\Delta C_{\mathrm{R}}\right)$ are expressed in percentage of the total plant content of the elements in the untreated soil. Values of $\mathrm{C}_{\mathrm{E}}, \Delta C_{\mathrm{P}}$ and $\Delta C_{\mathrm{R}}$ listed in the table are means of the three replicates, $\mathrm{BI}$ for plant $\left(\mathrm{BI} \mathrm{P}_{\mathrm{P}}\right)$ and for root $\left(\mathrm{BI}_{\mathrm{R}}\right)$ are the ratio of $\Delta C_{\mathrm{P}}$ to $C_{\mathrm{E}}$ and $\Delta C_{\mathrm{R}}$ to $C_{\mathrm{E}}$ respectively.

Table 5 (b). BI of the extractable trace elements with different extractants for soil $2 *$

\begin{tabular}{|c|c|c|c|c|c|c|c|c|c|c|c|c|c|c|c|}
\hline \multicolumn{6}{|c|}{ Element BI of DTPA-extractable fraction } & \multicolumn{5}{|c|}{$\mathrm{BI}$ of $\mathrm{HCl}-\mathrm{extractable}$ fraction } & \multicolumn{5}{|c|}{ BI of $\mathrm{NH}_{2} \mathrm{OH} . \mathrm{HCl}$ extractable fraction } \\
\hline & $\begin{array}{l}C_{\mathrm{E}} \\
(\%)\end{array}$ & $\begin{array}{l}\Delta C_{\mathrm{P}} \\
(\%)\end{array}$ & $\mathrm{BI}_{\mathrm{P}}$ & $\begin{array}{l}\Delta C_{\mathrm{R}} \\
(\%)\end{array}$ & $\mathrm{BI}_{\mathrm{R}}$ & $\begin{array}{l}C_{\mathrm{E}} \\
(\%)\end{array}$ & $\begin{array}{l}\Delta C_{\mathrm{P}} \\
(\%)\end{array}$ & $\mathrm{BI}_{\mathrm{P}}$ & $\begin{array}{l}\Delta C_{\mathrm{R}} \\
(\%)\end{array}$ & $\mathrm{BI}_{\mathrm{R}}$ & $\begin{array}{l}C_{\mathrm{E}} \\
(\%)\end{array}$ & $\begin{array}{l}\Delta C_{\mathrm{P}} \\
(\%)\end{array}$ & $\mathrm{BI}_{\mathrm{P}}$ & $\begin{array}{l}\Delta C_{\mathrm{R}} \\
(\%)\end{array}$ & $\mathrm{BI}_{\mathrm{R}}$ \\
\hline $\mathrm{Cr}$ & 0.52 & 25.6 & 49.2 & 57.0 & 109.6 & 3.0 & 39.9 & 13.3 & 52.6 & 17.5 & 8.2 & 23.0 & 2.8 & 64.6 & 7.9 \\
\hline $\mathrm{Mn}$ & 0.58 & 20.2 & 34.8 & 34.9 & 60.2 & 7.6 & 35.7 & 4.7 & 37.5 & 4.9 & 19.0 & 55.9 & 2.9 & 60.8 & 3.2 \\
\hline $\mathrm{Co}$ & 0.97 & 49.8 & 51.2 & 51.5 & 53.1 & 21.0 & 75.6 & 3.6 & 72.1 & 3.4 & 21.2 & 59.5 & 2.8 & 65.1 & 3.0 \\
\hline $\mathrm{Ni}$ & 3.2 & 54.4 & 17.0 & 54.6 & 17.1 & 5.4 & 8.9 & 1.6 & 41.3 & 7.6 & 9.6 & 20.1 & 2.1 & 13.9 & 1.4 \\
\hline $\mathrm{Zn}$ & 3.0 & 32.2 & 10.7 & 88.9 & 29.6 & 8.7 & 42.4 & 4.9 & 53.7 & 6.2 & 8.3 & 33.6 & 4.0 & 43.3 & 5.2 \\
\hline $\mathrm{Cu}$ & 6.2 & 24.5 & 4.0 & 16.0 & 2.6 & 13.3 & 21.6 & 1.6 & 24.8 & 1.9 & 51 & 32 & 0.63 & 22.8 & 0.45 \\
\hline $\mathrm{Cd}$ & 10.1 & 29.2 & 2.9 & 42.4 & 4.2 & 10.7 & 69.6 & 6.5 & 77.8 & 7.3 & 11.7 & 62.9 & 5.4 & 74.4 & 6.4 \\
\hline $\mathrm{Pb}$ & 4.0 & 39.9 & 10.0 & 45.3 & 11.3 & 22.3 & 39.1 & 1.8 & 59.1 & 2.7 & 21.7 & 38.7 & 1.8 & 71.1 & 3.3 \\
\hline
\end{tabular}

*The extractable trace elements $\left(C_{\mathrm{E}}\right)$ are expressed in percentage of the total content of the elements in the untreated soil and plant accumulation reduction of the elements in plant $\left(\Delta C_{\mathrm{P}}\right)$ and in $\operatorname{root}\left(\Delta C_{\mathrm{R}}\right)$ are expressed in percentage of the total plant content of the elements in the untreated soil. Values of $\mathrm{C}_{\mathrm{E}}, \Delta C_{\mathrm{P}}$ and $\Delta C_{\mathrm{R}}$ listed in the table are means of the three replicates, $\mathrm{BI}$ for plant $\left(\mathrm{BI}_{\mathrm{P}}\right)$ and for root $\left(\mathrm{BI}_{\mathrm{R}}\right)$ are the ratio of $\Delta C_{\mathrm{P}}$ to $C_{\mathrm{E}}$ and $\Delta C_{\mathrm{R}}$ to $C_{\mathrm{E}}$ respectively. 
Table 5 (c). BI of the extractable trace elements with different extractants for soil $3 *$

\begin{tabular}{|c|c|c|c|c|c|c|c|c|c|c|c|c|c|c|c|}
\hline \multicolumn{6}{|c|}{ Element BI of DTPA-extractable fraction } & \multicolumn{5}{|c|}{$\mathrm{BI}$ of $\mathrm{HCl}$-extractable fraction } & \multicolumn{5}{|c|}{$\mathrm{BI}$ of $\mathrm{NH}_{2} \mathrm{OH} . \mathrm{HCl}$ extractable fraction } \\
\hline & $\begin{array}{l}C_{\mathrm{E}} \\
(\%)\end{array}$ & $\begin{array}{l}\Delta C_{\mathrm{P}} \\
(\%)\end{array}$ & $\mathrm{BI}_{\mathrm{P}}$ & $\begin{array}{l}\Delta C_{\mathrm{R}} \\
(\%)\end{array}$ & $\mathrm{BI}_{\mathrm{R}}$ & $\begin{array}{l}C_{\mathrm{E}} \\
(\%)\end{array}$ & $\begin{array}{l}\Delta C_{\mathrm{P}} \\
(\%)\end{array}$ & $\mathrm{BI}_{\mathrm{P}}$ & $\begin{array}{l}\Delta C_{\mathrm{R}} \\
(\%)\end{array}$ & $\mathrm{BI}_{\mathrm{R}}$ & $\begin{array}{l}C_{\mathrm{E}} \\
(\%)\end{array}$ & $\begin{array}{l}\Delta C_{\mathrm{P}} \\
(\%)\end{array}$ & $\mathrm{BI}_{\mathrm{P}}$ & $\begin{array}{l}\Delta C_{\mathrm{R}} \\
(\%) \mathrm{C}_{\mathrm{E}}\end{array}$ & $\mathrm{BI}_{\mathrm{R}}$ \\
\hline $\mathrm{Cr}$ & 0.75 & 43.2 & 57.6 & 24.7 & 33.2 & 2.2 & 33.9 & 15.4 & 25.5 & 11.6 & 7.1 & 41.2 & 5.8 & 61.2 & 8.6 \\
\hline $\mathrm{Mn}$ & 0.80 & 30.0 & 37.5 & 38.0 & 47.5 & 17.7 & 51.1 & 2.9 & 1.2 & 44.2 & 25.9 & 44.0 & 1.7 & 62.3 & 2.4 \\
\hline Co & 1.7 & 43.9 & 25.8 & 45.0 & 26.5 & 23.3 & 50.6 & 2.2 & 44.8 & 1.9 & 23.4 & 65.6 & 2.8 & 40.2 & 1.7 \\
\hline $\mathrm{Ni}$ & 3.3 & 27.4 & 8.3 & 30.4 & 9.2 & 21.5 & 21.7 & 1.0 & 54.5 & 2.5 & 21.5 & 21.3 & 1.0 & 29.4 & 1.4 \\
\hline $\mathrm{Zn}$ & 2.2 & 29.5 & 13.4 & 27.9 & 12.7 & 19.1 & 39.2 & 2.1 & 37.8 & 2.0 & 19.0 & 30.9 & 1.6 & 41.8 & 2.2 \\
\hline $\mathrm{Cu}$ & 4.7 & 23.5 & 5.0 & 22.5 & 4.7 & 14.1 & 10.8 & 0.76 & 36.7 & 2.6 & 20.3 & 14.6 & 0.72 & 30.8 & 1.5 \\
\hline $\mathrm{Cd}$ & 15.0 & 44.3 & 2.9 & 45.0 & 3.0 & 21.5 & 28.0 & 1.3 & 36.6 & 1.7 & 34.7 & 41.5 & 1.2 & 47.5 & 1.4 \\
\hline $\mathrm{Pb}$ & 4.5 & 22.7 & 5.0 & 26.3 & 5.8 & 56.0 & 43.2 & 0.8 & 56.7 & 1.0 & 56.1 & 63.3 & 1.1 & 59.2 & 0.9 \\
\hline
\end{tabular}

*The extractable trace elements $\left(C_{\mathrm{E}}\right)$ are expressed in percentage of the total content of the elements in the untreated soil and plant accumulation reduction of the elements in plant $\left(\Delta C_{\mathrm{P}}\right)$ and in root $\left(\Delta C_{\mathrm{R}}\right)$ are expressed in percentage of the total plant content of the elements in the untreated soil. Values of $C_{E}, \Delta C_{P}$ and $\Delta C_{R}$ listed in the table are means of the three replicates, $B I$ for plant $\left(\mathrm{BI}_{\mathrm{P}}\right)$ and for root $\left(\mathrm{BI}_{\mathrm{R}}\right)$ are the ratio of $\Delta C_{\mathrm{P}}$ to $C_{\mathrm{E}}$ and $\Delta C_{\mathrm{R}}$ to $C_{\mathrm{E}}$ respectively.

Table 5 (d). BI of the extractable trace elements with different extractants for soil $4 *$

\begin{tabular}{|c|c|c|c|c|c|c|c|c|c|c|c|c|c|c|c|}
\hline \multicolumn{6}{|c|}{ Element BI of DTPA-extractable fraction } & \multicolumn{5}{|c|}{$\mathrm{BI}$ of $\mathrm{HCl}$-extractable fraction } & \multicolumn{5}{|c|}{$\mathrm{BI}$ of $\mathrm{NH}_{2} \mathrm{OH} . \mathrm{HCl}$ extractable fraction } \\
\hline & $\begin{array}{l}C_{\mathrm{E}} \\
(\%)\end{array}$ & $\begin{array}{l}\Delta C_{\mathrm{P}} \\
(\%)\end{array}$ & $\mathrm{BI}_{\mathrm{P}}$ & $\begin{array}{l}\Delta C_{\mathrm{R}} \\
(\%)\end{array}$ & $\mathrm{BI}_{\mathrm{R}}$ & $\begin{array}{l}C_{\mathrm{E}} \\
(\%)\end{array}$ & $\begin{array}{l}\Delta C_{\mathrm{P}} \\
(\%)\end{array}$ & $\mathrm{BI}_{\mathrm{P}}$ & $\begin{array}{l}\Delta C_{\mathrm{R}} \\
(\%)\end{array}$ & $\mathrm{BI}_{\mathrm{R}}$ & $\begin{array}{l}C_{\mathrm{E}} \\
(\%)\end{array}$ & $\begin{array}{l}\Delta C_{\mathrm{P}} \\
(\%)\end{array}$ & $\mathrm{BI}_{\mathrm{P}}$ & $\begin{array}{l}\Delta C_{\mathrm{R}} \\
(\%) \mathrm{C}_{\mathrm{E}}\end{array}$ & $\mathrm{BI}_{\mathrm{R}}$ \\
\hline $\mathrm{Cr}$ & 0.37 & 25.7 & 69.4 & 28.0 & 75.7 & 1.3 & 12.6 & 9.7 & 16.9 & 13.0 & 6.3 & 29.0 & 4.6 & 21.6 & 3.4 \\
\hline Mn & 1.27 & 57.3 & 45.1 & 76.3 & 60.0 & 3.6 & 34.1 & 9.5 & 59.8 & 16.6 & 27.9 & 56.2 & 2.0 & 53.2 & 1.9 \\
\hline Co & 0.73 & 59.8 & 81.9 & 51.6 & 70.7 & 26.4 & 49.0 & 1.9 & 39.6 & 1.5 & 26.6 & 59.3 & 2.2 & 57.3 & 2.2 \\
\hline $\mathrm{Ni}$ & 1.26 & 25.5 & 20.2 & 28.9 & 22.9 & 12.7 & 29.4 & 2.3 & 34.0 & 2.7 & 12.8 & 48.8 & 3.8 & 40.6 & 3.2 \\
\hline $\mathrm{Zn}$ & 0.90 & 28.4 & 31.5 & 44.5 & 49.4 & 11.4 & 28.3 & 2.5 & 41.7 & 3.7 & 15.8 & 41.2 & 2.6 & 56.5 & 3.6 \\
\hline $\mathrm{Cu}$ & 7.3 & 34.9 & 4.8 & 37.0 & 5.1 & 14.5 & 53.7 & 3.7 & 46.4 & 3.2 & 23.6 & 51.9 & 2.2 & 62.0 & 2.6 \\
\hline $\mathrm{Cd}$ & 8.7 & 10.4 & 1.2 & 17.0 & 1.9 & 9.7 & 41.5 & 4.3 & 56.3 & 5.8 & 10.7 & 65.3 & 6.1 & 78.5 & 7.3 \\
\hline $\mathrm{Pb}$ & 3.4 & 19.4 & 5.7 & 36.4 & 10.7 & 18.7 & 34.2 & 1.8 & 66.3 & 3.5 & 18.8 & 25.9 & 1.4 & 39.5 & 2.1 \\
\hline
\end{tabular}

*The extractable trace elements $\left(C_{\mathrm{E}}\right)$ are expressed in percentage of the total content of the elements in the untreated soil and plant accumulation reduction of the elements in plant $\left(\Delta C_{\mathrm{P}}\right)$ and in root $\left(\Delta C_{\mathrm{R}}\right)$ are expressed in percentage of the total plant content of the elements in the untreated soil. Values of $\mathrm{C}_{\mathrm{E}}, \Delta C_{\mathrm{P}}$ and $\Delta C_{\mathrm{R}}$ listed in the table are means of the three replicates, $\mathrm{BI}$ for plant $\left(\mathrm{BI}_{\mathrm{P}}\right)$ and for root $\left(\mathrm{BI}_{\mathrm{R}}\right)$ are the ratio of $\Delta C_{\mathrm{P}}$ to $C_{\mathrm{E}}$ and $\Delta C_{\mathrm{R}}$ to $C_{\mathrm{E}}$ respectively.

Table 5 (e). BI of the extractable trace elements with different extractants for soil $5^{*}$

\begin{tabular}{|c|c|c|c|c|c|c|c|c|c|c|c|c|c|c|c|}
\hline \multicolumn{6}{|c|}{ Element BI of DTPA-extractable fraction } & \multicolumn{5}{|c|}{$\mathrm{BI}$ of $\mathrm{HCl}$-extractable fraction } & \multicolumn{5}{|c|}{$\mathrm{BI}$ of $\mathrm{NH}_{2} \mathrm{OH} . \mathrm{HCl}$ extractable fraction } \\
\hline & $\begin{array}{l}C_{\mathrm{E}} \\
(\%)\end{array}$ & $\begin{array}{l}\Delta C_{\mathrm{P}} \\
(\%)\end{array}$ & $\mathrm{BI}_{\mathrm{P}}$ & $\begin{array}{l}\Delta C_{\mathrm{R}} \\
(\%)\end{array}$ & $\mathrm{BI}_{\mathrm{R}}$ & $\begin{array}{l}C_{\mathrm{E}} \\
(\%)\end{array}$ & $\begin{array}{l}\Delta C_{\mathrm{P}} \\
(\%)\end{array}$ & $\mathrm{BI}_{\mathrm{P}}$ & $\begin{array}{l}\Delta C_{\mathrm{R}} \\
(\%)\end{array}$ & $\mathrm{BI}_{\mathrm{R}}$ & $\begin{array}{l}C_{\mathrm{E}} \\
(\%)\end{array}$ & $\begin{array}{l}\Delta C_{\mathrm{P}} \\
(\%)\end{array}$ & $\mathrm{BI}_{\mathrm{P}}$ & $\begin{array}{l}\Delta C_{\mathrm{R}} \\
(\%) \mathrm{C}_{\mathrm{E}}\end{array}$ & $\mathrm{BI}_{\mathrm{R}}$ \\
\hline $\mathrm{Cr}$ & 0.91 & 35.7 & 39.3 & 36.7 & 40.3 & 13.6 & 33.1 & 2.4 & 55.7 & 4.1 & 2.7 & 36.0 & 13.3 & 38.1 & 14.1 \\
\hline $\mathrm{Mn}$ & 2.3 & 34.1 & 14.8 & 69.9 & 30.4 & 5.5 & 15.1 & 2.7 & 12.7 & 2.3 & 19.4 & 40.7 & 2.1 & 42.8 & 2.2 \\
\hline Co & 7.7 & 49.6 & 6.4 & 83.3 & 10.8 & 8.5 & 35.9 & 4.2 & 43.2 & 5.1 & 25.9 & 47.7 & 1.8 & 43.2 & 1.7 \\
\hline $\mathrm{Ni}$ & 1.6 & 16.7 & 10.4 & 22.7 & 14.2 & 11.1 & 17.2 & 1.5 & 21.1 & 1.9 & 11.1 & 22.4 & 2.0 & 20.0 & 1.8 \\
\hline $\mathrm{Zn}$ & 2.0 & 70.1 & 35.0 & 82.4 & 41.2 & 16.6 & 26.8 & 1.6 & 45.1 & 2.7 & 16.6 & 73.3 & 4.4 & 78.0 & 4.7 \\
\hline $\mathrm{Cu}$ & 5.7 & 23.5 & 4.1 & 21.1 & 3.7 & 7.4 & 13.7 & 1.9 & 14.1 & 1.9 & 27.5 & 44.0 & 1.6 & 33.0 & 1.2 \\
\hline $\mathrm{Cd}$ & 12.4 & 22.9 & 1.8 & 26.0 & 2.1 & 11.5 & 39.1 & 3.4 & 50.5 & 4.4 & 31.8 & 54.0 & 1.7 & 60.1 & 1.9 \\
\hline $\mathrm{Pb}$ & 3.2 & 13.1 & 4.1 & 15.7 & 4.9 & 18.3 & 35.5 & 1.9 & 34.5 & 1.9 & 18.3 & 48.9 & 2.7 & 45.8 & 2.5 \\
\hline
\end{tabular}

*The extractable trace elements $\left(C_{\mathrm{E}}\right)$ are expressed in percentage of the total content of the elements in the untreated soil and plant accumulation reduction of the elements in plant $\left(\Delta C_{\mathrm{P}}\right)$ and in $\operatorname{root}\left(\Delta C_{\mathrm{R}}\right)$ are expressed in percentage of the total plant content of the elements in the untreated soil. Values of $C_{\mathrm{E}}, \Delta C_{\mathrm{P}}$ and $\Delta C_{\mathrm{R}}$ listed in the table are means of the three replicates, $\mathrm{BI}$ for plant $\left(\mathrm{BI}_{\mathrm{P}}\right)$ and for root $\left(\mathrm{BI}_{\mathrm{R}}\right)$ are the ratio of $\Delta C_{\mathrm{P}}$ to $C_{\mathrm{E}}$ and $\Delta C_{\mathrm{R}}$ to $C_{\mathrm{E}}$ respectively. 
fodder. Also Maiz et al. (1997) achieved good results using DTPA as an extractant to determine the available metal fractions of $\mathrm{Cd}, \mathrm{Pb}, \mathrm{Zn}, \mathrm{Cu}, \mathrm{Mn}, \mathrm{Ni}, \mathrm{Fe}$ and $\mathrm{Cr}$ in soils. Although $\mathrm{HCl}$ and $\mathrm{NH}_{2} \mathrm{OH}$. $\mathrm{HCl}$ removed more of the metals, they had lower BI values. The $\mathrm{HCl}$ extractant dissolves some of the more insoluble minerals though an acid attack, has strong cation-exchange potential, and keeps the cations in solution by forming chloride complexes. Therefore, some unavailable fractions were extracted, leading to lower BI values. The $\mathrm{NH}_{2} \mathrm{OHHCl}$ extractant is commonly used in fractionation for the elements in reducible forms or excluded in the reducible Fe-Mn oxides (Shuman, 1985; Lake and Lester, 1984), which are thought to be less available for plants. The BI values for $\mathrm{Cd}$ in soils 2 and 4 are somewhat different from other soils. They are not in the order of $\mathrm{BI}(\mathrm{DTPA})>\mathrm{BI}(\mathrm{HCl})>\mathrm{BI}\left(\mathrm{NH}_{2} \mathrm{OH} . \mathrm{HCl}\right)$. The average values of $\mathrm{BI}$ for DTPA-extractable $\mathrm{Cd}$ for soils 2 and were 2.9 and 1.2 respectively, which were lower than those for $\mathrm{HCl}$ and $\mathrm{NH}_{2} \mathrm{OH} . \mathrm{HCl}$, which were 6.5 and 4.3 respectively for the $\mathrm{HCl}$ fraction, and 5.4 and 6.1 respectively for the $\mathrm{NH}_{2} \mathrm{OH} . \mathrm{HCl}$ fraction. This phenomenon was probably caused by the addition of $\mathrm{CaO}$ for the $\mathrm{pH}$ adjustment. It agrees with Andersson and Persson's observations (1984) that occasional increases were observed in the uptake of $\mathrm{Cd}$ after small amounts of $\mathrm{CaO}$ had been added. They suggested that the effect was caused by the addition of $\mathrm{Ca}$, resulting in the removal of the exchangeable $\mathrm{Cd}$ from the soil colloids, thereby temporarily rendering it increasingly available to plants. Also we can see from Table 5(a) to 5(e) that the $\mathrm{BI}$ values for $\mathrm{HCl}$ and $\mathrm{NH}_{2} \mathrm{OH} . \mathrm{HCl}$ extractable $\mathrm{Cd}$ for soils 2 and 4 are higher than the BI values for other soils. The explanation could be from the differences of the physical properties of the soils. Soils 2 and 4 have higher cation exchange capacity than other soils (see in Table 1), and the cation exchange reactions in soils 2 and 4 are easier than in the other soils. Therefore only in soils 2 and 4, could we observe the increase of Cd uptake in plant after $\mathrm{CaO}$ was added.

\section{Bioavailability of different trace elements}

Variations of BI among different trace elements were also examined. An approximate estimate could be made from Table 5 that, in general, $\mathrm{Cr}, \mathrm{Mn}, \mathrm{Zn}$ and $\mathrm{Ni}$ had higher BI values. The mean values for the DTPA extractable fraction were 49.4, 33.320 .8 and 13.5, respectively. Whereas $\mathrm{Cu}, \mathrm{Cd}$ and $\mathrm{Pb}$ possessed lower values of 3.9, 2.3 and 5.8, respectively. This corresponded to the results obtained by Chen et al. (1996), in which $\mathrm{Mn}, \mathrm{Ni}, \mathrm{Cr}$ and $\mathrm{V}$ had high $\mathrm{BI}$ values, $\mathrm{Cu}$ had a low $\mathrm{BI}$ value and $\mathrm{Zn}, \mathrm{Co}$ and $\mathrm{Pb}$ in the middle range. It should be emphasised that the BI variations among different trace elements showed the same pattern for different soils. From this, we may ascertain that BI can be used for different soils as an index for the study of bioavailability.

From the definition of BI we can see that two factors can determine the difference of BI values among the elements. One is the different extractability of elements. Data from Table 5 shows that $\mathrm{Cr}, \mathrm{Mn}$ and $\mathrm{Co}$ had low $C_{\mathrm{e}}$, but the corresponding BI values were high. On the contrary, $\mathrm{Cu}, \mathrm{Cd}$ and $\mathrm{Pb}$ had high $C_{\mathrm{e}}$ values, but the $\mathrm{BI}$ was low. Different elements exist as different chemical forms in soils and their interactions with the extracts were not the same. For some elements, only the most available species, such as complex ions in soil solutions and easily exchangeable ions, were extracted. Although these species comprise a small proportion, they are the main source of the bioavailable fraction. Accordingly, high BI values were obtained. Another effect was the difference in accumulation and reduction in uptake of the elements in plants caused by the soil treatments. However, as can be found in Table 5, accumulation and reduction values $\Delta C_{\mathrm{p}}$ did not drastically differ. This is understandable because plants can develop an effective mechanism of active uptake and transport to obtain metal ions from less available fractions in order to obtain nutrients for growing.

\section{Relationship between the bioavailability index and soil properties}

Data in Table 5 shows that the BI values did not differ significantly among the soils. But it was notable that for the DTPA extractable fraction, soils 2 and 4 had slightly higher BI values than for most of the elements, which could be attributed to the much higher CEC and lower $\mathrm{pH}$ than for the other soils. The higher CEC and lower $\mathrm{pH}$ of soils would stimulate the release of more trace elements during incubation and during the plant's growing processes, thus improving the uptake of the elements to the plant. However, it is unclear which factor is predominant between $\mathrm{pH}$ and CEC.

Although variations of $\mathrm{BI}$ values among the soils were observed, they are not clearly related to soil properties. Bioavailability index is a relative accumulation and reduction measure by comparing treated and untreated soil. That means the comparison is made within the same soil. Also we can see from Table 5 that the BI values for plants are not different from those for roots, which may also be attributed to relative BI values obtained between the treated and untreated samples of the same soil. Therefore it may be expected that quantitative differentiation among the extractants with respect to trace element bioavailability, or comparison of the bioavailability among elements, could be achieved while minimizing the influence of soil properties.

\section{CONCLUSION}

The results of this study indicated that BI and the 
corresponding experimental method could be used to establish quantitative relationships between soil extractability and the uptake of trace elements by plants. Therefore, a quantitative measure could be established for the comparison and evaluation of bioavailability of different extractable fractions. As described above, the BI of the DTPA-extractable fraction was much higher than that of $\mathrm{HCl}$ and $\mathrm{NH}_{2} \mathrm{OHHCl}$ extractable fractions. This indicates that the DTPA extractable fraction represented a highly available fraction of the total content. Variation of BI among different trace elements mirrors the differences of bioavailability among the elements. In this study higher BI values for $\mathrm{Cr}, \mathrm{Mn}, \mathrm{Zn}$ and $\mathrm{Co}$ and lower ones for $\mathrm{Cu}, \mathrm{Cd}$ and $\mathrm{Pb}$ were observed. This difference was mainly attributed to the differences in extractability among the elements.

The influence of soil properties upon the BI values was insignificant. Quantitative differentiation among the extractants with respect to trace element bioavailability or the comparison of bioavailability among elements, could be achieved based on the BI method for different types of soil while minimising the effects of soil properties.

\section{ACKNOWLEDGEMENT}

This work was funded by the National Natural Science Foundation of China and the Research Center for Eco-Environmental Sciences (RCEES-KIP-9901).

\section{REFERENCES}

Alegria, A., Barbera, R., Boluda, R., Errecalde, F., Farre, R. and Lagarda, M.J. 1991. Environmental Cd, Pb and Ni contamination: Possible relationship between soil and vegetable content. Fresenius J. Anal. Chem., 339, 654-657.

Andersson, A. and Persson, J. 1984. Uptake in agricultural crops of trace elements from fly ash. Coal health-environment project, technical Paper 25, The Swedish state power board, pp.36 Vallingby, Sweden.

Bingham, F.T., Page, A.L., Hahler, R.J. and Ganje, T.J. 1975. Growth and cadmium accumulation of plants grown on a soil treated with cadmium-enriched sewage sludge. J Environ. Qual., 4, 207-211.

Chen, B., Shan, X.Q. and Qian, J. 1996. Bioavailability index for quantitative evaluation of plant availability of extractable soil trace elements. Plant Soil, 186, 275-283.

Das, A.K., Chakraborty, R., Cervera, M.L. and Guardia, M. 1995. Metal speciation in solid matrices, Talanta, 42, 1007-1030.

Davies, B.E. 1992. Inter-relationships between soil properties and the uptake of cadimum, copper, lead and zinc from contaminated soils by radish (Raphanus stivus L.). Water Air Soil Pollut., 63, 331-342.

Kennedy, V.H., Sanchez, A.L. and Olughton, A.P. 1997. Use of single and sequential chemical extractants to assess radionuclide and heavy metal availability from soils for root uptake. Analyst, 122, 89-100.

Lake, P.W.W. and Lester, J.N. 1984. Fractionation, characterization, and speciation of heavy metals in sewage sludge and sludge-amended soils. J. Environ. Qual., 13, $175-183$.

Lindsay, W.L. and Norvell, W.A., 1978. Development of a DTPA soil test for zinc, iron, manganese and copper. Soil Sci. Soc. Am. J., 42, 421-428.

Maiz, I., Esnaola, M.V. and Millan, E. 1997. Evaluation of heavy metal availability in contaminated soils by a short sequential extraction procedure. Sci. Total Environ., 206 107-115.

McNeal, M., Severson, R.C. and Gough, L.P. 1985. The occurrence of extractable elements in soils from the northern great plains. Soil Sci. Soc. Am. J., 49, 873-881.

Nelson, D.W., Sommers, L.E. 1982. Total carbon, organic carbon, and organic matter. In: Page, A.L., Miller, R.H. and Keeney, D.R. (eds), Methods of Soil Analysis, Part 2. pp. 539-579. America Society of Agronomy, Madison, WI.

Quevauviller, P., Sloot, H. A., Ure, A., Muntau, H., Gomez, A., and Rauret, R. 1996, Conclusions of the workshop: harmonization of leaching/extraction tests for environmental risk assessment. Sci. Total Environ., 178, 133-139.

Randall, G.W., Shulte, E.E. and Corey, R.B. 1976. Correlation of plant manganese with extractable soil manganese and soil factors. Soil Sci. Soc. Am. J., 40, 282-286.

Rhoades, J.D. 1982. Cation-exchange capacity. In: Page, A.L., Miller, R.H., Keeney, D.R. (Eds.), Methods of Soil Analysis, Part 2. pp. 149-158. America Society of Agronomy, Madison, WI.

Sauerbeck, D.R. and Hein A. 1991. The nickel uptake from different soils and its prediction by chemical extractions. Water Air soil Pollut., 57/58, 861-871.

Shuman, L.M., 1985. Fractionation method for soil. Soil Sci., 140, 11-22.

Singh, B.R. and Narwal, R.P. 1984. Plant Availability of heavy metals in a sludge-treated soil: II. Metal extractability compared with plant metal uptake. J.Environ. Qual. 13, 344-348.

Soon, Y.K. and Bates, T.E. 1982. Chemical pools of cadmium nickel, and zinc in polluted soils and some preliminary indications of their availability to plants. J. Soil Sci., 33, 477-488.

Zhang, S.Z. and Shan, X.Q. 1997, The determination of Rare Earth Elements in Soil by Inductively Coupled Plasma Mass Spectrometry. At. Spectro. 18, 140-144. 
CSBZhang 21/11/02 1:50 pm Page 124 